\title{
Road Map for Development of Crystal-Tolerant High Level Waste Glasses
}

PNNL

J. Matyáš

J. D. Vienna

DOE-ORP

\section{A. A. Kruger}

SRNL

D. K. Peeler

K. M. Fox

C. C. Herman

May 2014

Savannah River National Laboratory

Savannah River Nuclear Solutions, LLC Aiken, SC 29808

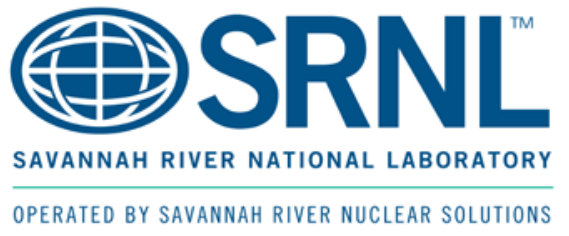

Pacific Northwest National Laboratory

P.O. Box 999

Richland, WA 99352

\section{Pacific Northwest}

NATIONAL LABORATORY

Proudly Operated by Battelle Since 1965 


\section{DISCLAIMER}

This work was prepared under an agreement with and funded by the U.S. Government. Neither the U.S. Government or its employees, nor any of its contractors, subcontractors or their employees, makes any express or implied:

1. warranty or assumes any legal liability for the accuracy, completeness, or for the use or results of such use of any information, product, or process disclosed; or

2. representation that such use or results of such use would not infringe privately owned rights; or

3. endorsement or recommendation of any specifically identified commercial product, process, or service.

Any views and opinions of authors expressed in this work do not necessarily state or reflect those of the United States Government, or its contractors, or subcontractors.

Printed in the United States of America

Prepared for

U.S. Department of Energy 
PNNL-23363

SRNL-STI-2013-00734

Revision 0

\section{REVIEWS AND APPROVALS}

AUTHORS:
Iad Mratga
$\frac{5 \longdiv { 2 0 / 1 4 }}{\text { Date }}$
per e-mail from J. Vienna
$5 / 21 / 14$

J. D. Vienna, Pacific Northwest National Laboratory

Date

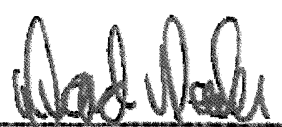

D. K. Peeler, Savannah River National Laboratory
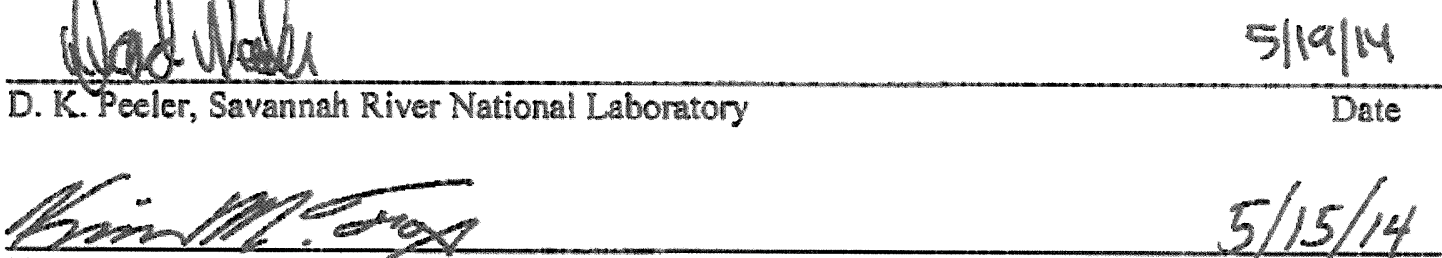

K. M. Fox, Savannah River National Laboratory

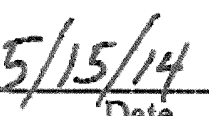

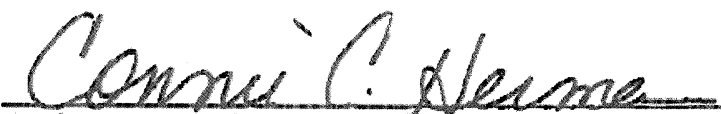
$5 / 20 / 14$
C. C. Herman, Savannah River National Laboratory

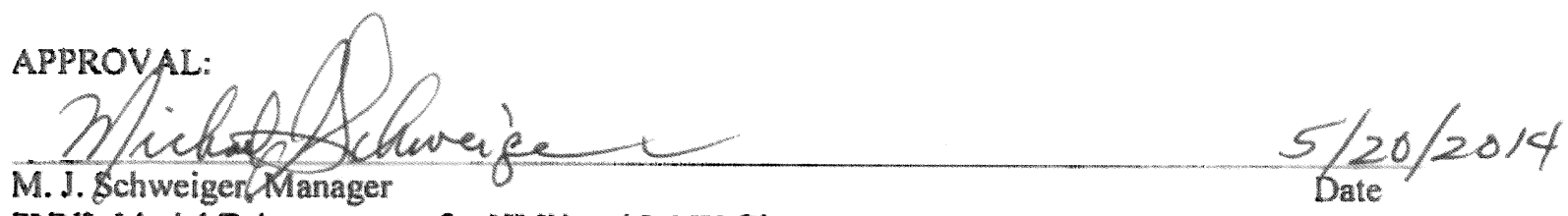

PNNL Model Enhancements for HLW and LAW Glasses

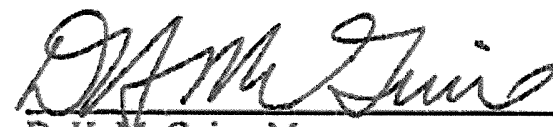

D. H. McGuire, Manager

SRNL Process Technology Programs

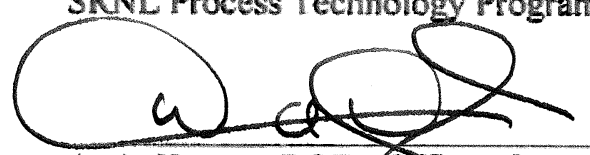

A. A. Kruger, DOE - Otfise of River Protection

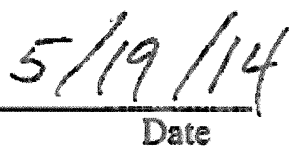

$$
20 \cdot 5 \cdot 14
$$


PNNL-23363

SRNL-STI-2013-00734

Revision 0

\section{EXECUTIVE SUMMARY}

The U.S. Department of Energy (DOE) is building a Tank Waste Treatment and Immobilization Plant (WTP) at the Hanford Site in Washington to remediate 55 million gallons of radioactive waste that is being temporarily stored in 177 underground tanks. Efforts are being made to increase the loading of Hanford tank wastes in glass while meeting melter lifetime expectancies and process, regulatory, and product quality requirements.

This road map guides the research and development for formulation and processing of crystaltolerant glasses, identifying near- and long-term activities that need to be completed over the period from 2014 to 2019. The primary objective is to maximize waste loading for Hanford waste glasses without jeopardizing melter operation by crystal accumulation in the melter or melter discharge riser. The potential applicability to the Savannah River Site (SRS) Defense Waste Processing Facility (DWPF) will also be addressed in this road map.

The planned research described in this road map is motivated by the potential for substantial economic benefits (significant reductions in glass volumes) that will be realized if the current constraints ( $T_{1 \%}$ for WTP and $T_{L}$ for DWPF) are approached in an appropriate and technically defensible manner for defense waste and current melter designs. The basis of this alternative approach is an empirical model predicting the crystal accumulation in the WTP glass discharge riser and melter bottom as a function of glass composition, time, and temperature. When coupled with an associated operating limit (e.g., the maximum tolerable thickness of an accumulated layer of crystals), this model could then be integrated into the process control algorithms to formulate crystal-tolerant high-level waste (HLW) glasses targeting high waste loadings while still meeting process related limits and melter lifetime expectancies.

The modeling effort will be an iterative process, where model form and a broader range of conditions, e.g., glass composition and temperature, will evolve as additional data on crystal accumulation are gathered. Model validation steps will be included to guide the development process and ensure the value of the effort (i.e., increased waste loading and waste throughput).

A summary of the stages of the road map for developing the crystal-tolerant glass approach, their estimated durations, and deliverables is provided. 


\section{TABLE OF CONTENTS}

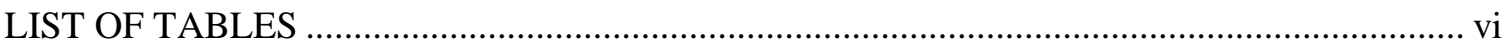

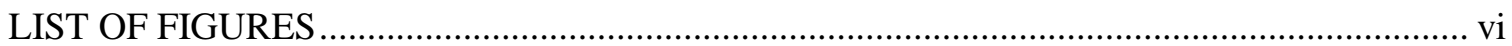

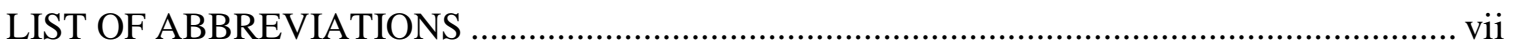

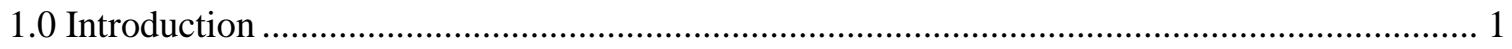

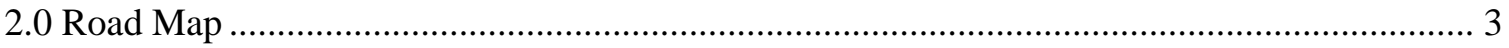

2.1 Review Past and Current Findings and Experimental Data................................................ 3

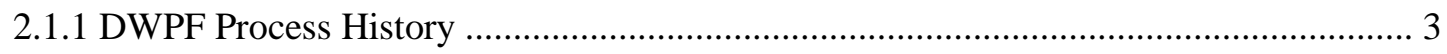

2.1.2 Crystal Settling Studies Literature Review ...................................................................... 4

2.1.3 Assessment of WTP HLW Melter Design ...................................................................... 4

2.2 Develop an Empirical Model of Crystal Accumulation...................................................... 4

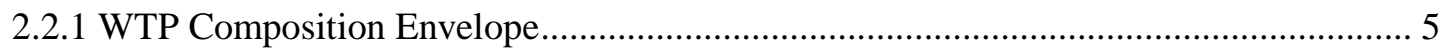

2.2.2 Glass Selection and Characterization............................................................................ 5

2.2.3 Model Fitting and Quantification of Uncertainties ........................................................ 5

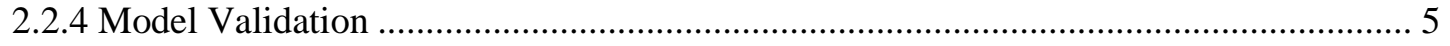

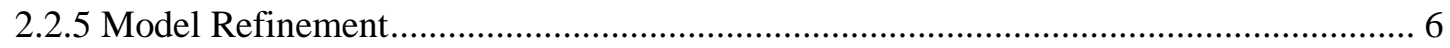

2.3 Identify Engineering Methods for Monitoring and Mitigating Crystal Accumulation.......... 6

2.3.1 Develop Online Monitoring of Crystal Accumulation in the Riser ................................ 6

2.3.2 Develop and demonstrate engineering solutions to mitigate accumulation of crystals... 6

2.3.3 Fluid Dynamic Modeling of Riser Accumulation and Clearing .................................... 6

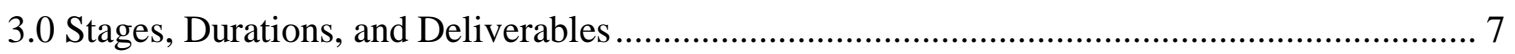

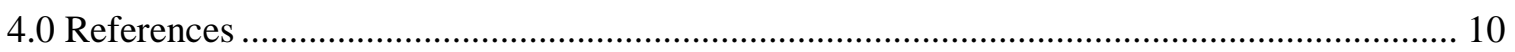


PNNL-23363

SRNL-STI-2013-00734

Revision 0

\section{LIST OF TABLES}

Table 3-1. Road Map Stages, Durations, and Deliverables.......................................................... 8

\section{LIST OF FIGURES}

Figure 1-1. Estimated Hanford HLW Glass Volume as a Function of Crystal Concentration....... 2 
PNNL-23363

SRNL-STI-2013-00734

Revision 0

\section{LIST OF ABBREVIATIONS}

$\begin{array}{ll}\text { DOE } & \text { U.S. Department of Energy } \\ \text { DWPF } & \text { Defense Waste Processing Facility } \\ \text { EGCR } & \text { Experimental Glass Composition Region } \\ \text { HLW } & \text { High-Level Waste } \\ \text { IDMS } & \text { Integrated DWPF Melter System } \\ \text { JHCM } & \text { Joule-heated ceramic melters } \\ \text { LAW } & \text { Low-Activity Waste } \\ \text { ORP } & \text { U.S. Department of Energy - Office of River Protection } \\ \text { PNNL } & \text { Pacific Northwest National Laboratory } \\ \text { SRNL } & \text { Savannah River National Laboratory } \\ \text { SRR } & \text { Savannah River Remediation } \\ \text { SRS } & \text { Savannah River Site } \\ \text { WTP } & \text { Hanford Tank Waste Treatment and Immobilization Plant } \\ \text { WVDP } & \text { West Valley Demonstration Project }\end{array}$


PNNL-23363

SRNL-STI-2013-00734

Revision 0

\subsection{Introduction}

The U.S. Department of Energy (DOE) is building a Tank Waste Treatment and Immobilization Plant (WTP) at the Hanford Site in Washington to remediate 55 million gallons of radioactive waste that is being temporarily stored in 177 underground tanks. The low-activity waste (LAW) fraction will be partitioned from the high-level waste (HLW). Both the LAW and HLW will then be vitrified in borosilicate glass with Joule-heated ceramic melters (JHCM). ${ }^{1}$ The JHCM technology was successfully used from 1996 to 2002 at the West Valley Demonstration Project (WVDP) in New York and has been in continuous use at the Defense Waste Processing Facility (DWPF) at the Savannah River Site (SRS) since 1996. However, efforts are being made to fully utilize this technology and increase the loading of Hanford tank wastes in glass while meeting melter lifetime expectancies and process, regulatory, and product quality requirements.

To achieve this goal, the DOE Office of River Protection (ORP) has assembled a research and development team that brings unique experience, capabilities, and operational experience that will be applied to significantly increase the waste loadings of glasses over the composition regions that WTP expects to process while balancing impacts to melter performance and lifetime. Recent experimental efforts have significantly expanded the composition regions and waste loadings of glasses beyond the point used in project planning models. In fact, recent glass formulation and melter testing data have suggested that significant increases in waste loading in HLW and LAW glasses are possible over current system planning estimates. ${ }^{2}$ The data (although limited in some cases) were evaluated to determine a set of constraints and models that could be used to estimate the maximum loading of specific waste compositions in glass. It was recognized that some of the models are preliminary in nature and that some do not currently address prediction uncertainties that would be needed before they could be used in plant operations. However, the assessments based on these enhanced models or advanced glass formulations demonstrate the potential for significant improvement in waste loading if higher crystal content can be routinely processed in the HLW glass melters.

Historically, crystallization constraints are placed in process control systems to prevent premature or catastrophic failure of JHCM through bulk devitrification or crystal accumulation and to mitigate negative impacts of crystals as glass is produced. Belsher and Meinert identified five constraints that were most influential on the estimated Hanford HLW glass volumes. ${ }^{3}$ One of those constraints was the limit of no more than 1 vol\% spinel crystals in equilibrium with the melt $\left(T_{1 \%}\right)$ at a temperature of $950{ }^{\circ} \mathrm{C}$. The 1 vol \% and $950{ }^{\circ} \mathrm{C}$ are somewhat arbitrary points of reference that have only indirect bearing on the melter lifetime. The current reason for their use is based on good operational experience (non-existence of crystal accumulation related melter failures) with over 300 melter tests ${ }^{4}$ at melter scales ranging from $0.2 \%$ to $88 \%$ of the full scale. This constraint is the focus of the current investigation.

The planned method of controlling crystallization in the WTP HLW melter is to adjust glass composition so that the predicted $T_{1 \%}$ (using glass composition-property models) is below $950{ }^{\circ} \mathrm{C}$ (accounting for applicable uncertainties). In contrast, a spinel $T_{L}$ constraint is used in DWPF to minimize the risk of bulk devitrification in the melt pool. The DWPF melter is operated with a model that predicts the spinel liquidus temperature $\left(T_{L}\right)$ of the glass as a function of its composition. The DWPF process control system then adds both model and measurement uncertainties to this predicted value - effectively increasing the predicted $T_{L}$. After the application of uncertainties, the resulting $T_{L}$ value must be at least $100{ }^{\circ} \mathrm{C}$ below the nominal operating temperature $1150{ }^{\circ} \mathrm{C}$ in order for the feed to be acceptable for transfer to the melter. 
PNNL-23363

SRNL-STI-2013-00734

Revision 0

The $100{ }^{\circ} \mathrm{C}$ offset provides an additional margin of safety to prevent bulk devitrification. This approach has been used at DWPF since radioactive startup in 1996 and has been successful at eliminating bulk devitrification within the melt pool leading to catastrophic melter failure or significant processing issues associated with crystallization in or from the melt pool. In fact, the first DWPF melter operated for 8 years, exceeding expected melter operational life periods (2-6 years) that were based on refractory wear estimates. ${ }^{5}$ The second melter has continually supported facility operations since March 2003, again exceeding the design life by a considerable margin. Although the $T_{L}$ model has been effective for DWPF, the model is potentially conservative in that it may limit waste loading to less than what would otherwise be possible with respect to alternative melter processing constraints while maintaining a chemically durable glass as well as satisfying other process related constraints (e.g., viscosity). Some crystalline phases, such as spinel, do not impact the durability of the waste form but may accumulate in the melter and restrict its operation. Thus, the potential exists for formulating high-waste loaded and durable glasses if an alternative strategy for operating a melter with some amount of tolerable crystals can be developed and implemented. ${ }^{\mathrm{a}}$

The Hanford Tank Waste Operations Simulator (HTWOS) identified the $T_{1 \%}$ constraint as one of the five most influential or restrictive constraints for estimated Hanford HLW glass volumes. DOE-ORP has initiated a program to develop an appropriate and defensible crystallization control strategy to modify or replace the current $T_{1 \%}$ approach. ${ }^{6,7}$ The significance of increased crystal limit on reduction of glass volumes is visualized in Figure 1-1. For example, an increase in concentration from 1 to $2 \mathrm{vol} \%$ of spinel crystals in glass at $950{ }^{\circ} \mathrm{C}$ results in decrease of glass mass by more than 2,000 MT. ${ }^{2}$ Although, this is also an ad-hoc constraint that doesn't directly correlate to the risk of melt discharge riser pluggage or other melter failure modes.

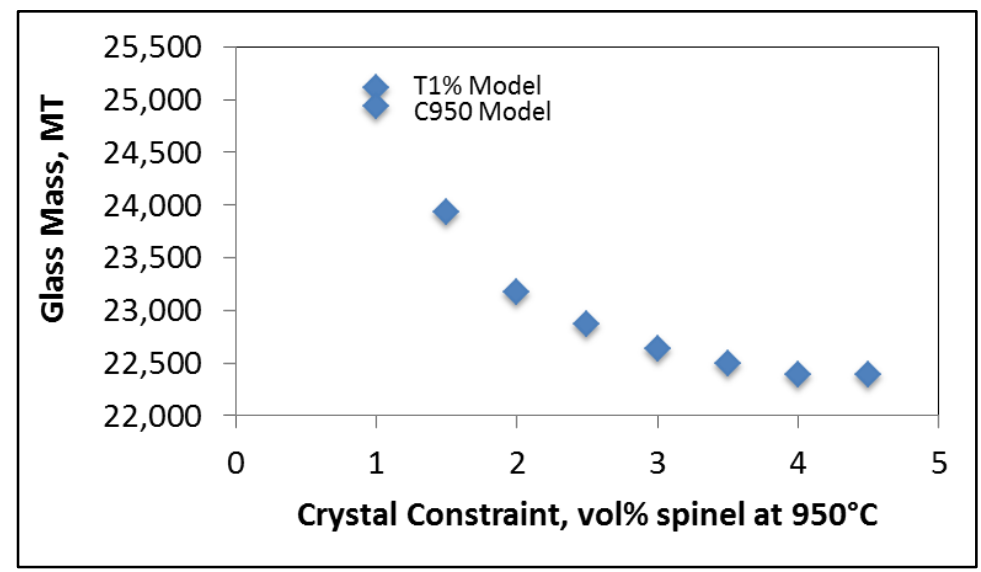

\section{Figure 1-1. Estimated Hanford HLW Glass Volume as a Function of Crystal} Concentration ${ }^{2}$

The planned research described in this road map is motivated by the potential for substantial economic benefits (significant reductions in glass volumes) that will be realized if the current constraints ( $T_{1 \%}$ for WTP and $T_{L}$ for DWPF) are approached in an appropriate and technically defensible manner for defense waste and current melter designs. The basis of this alternative

\footnotetext{
${ }^{\text {a }}$ It should be noted that for DWPF, assessments of reducing the $100^{\circ} \mathrm{C}$ offset between the nominal melter temperature and the $1050{ }^{\circ} \mathrm{C} \mathrm{T}_{\mathrm{L}}$ limit (without uncertainties applied) has also been an alternative method considered to reduce or minimize the impact of $\mathrm{T}_{\mathrm{L}}$ predictions on projected waste loadings.
} 
PNNL-23363

SRNL-STI-2013-00734

Revision 0

approach is an empirical model predicting the crystal accumulation in the WTP melt discharge riser and melter bottom as a function of glass composition, time, and temperature. When coupled with an associated operating limit (e.g., the maximum tolerable thickness of an accumulated layer of crystals), this model could then be integrated into the process control algorithms to formulate crystal-tolerant HLW glasses targeting high waste loadings while still meeting process related limits and melter lifetime expectancies. The goal of this program is to develop a fundamental and technically sound approach that can be implemented in WTP operation (and potentially DWPF, assuming significant improvements in projected waste loadings could be shown ${ }^{\mathrm{b}}$ ). Since WTP and DWPF have different melter designs and operating strategies, different approaches will likely be necessary.

\subsection{Road Map}

This road map guides the research and development of constraints that will allow for some crystals in the melt while avoiding the deleterious effects of crystal sludge buildup. It will also include developing data to allow for the constraints to be met during glass formulation. Nearand long-term activities that need to be completed over the period from 2014 to 2019 are identified. Although the primary objective is to develop constraints and data for use at WTP, the potential applicability to DWPF will also be addressed in this road map. The objective of this road map is to develop a strategy for operating the WTP HLW melter that allows for a controlled amount of crystallization in the glass in order to achieve high waste loadings, which ultimately result in reduction of the overall glass volume and canister count. This objective will be achieved by completing the activities/tasks described below.

\subsection{Review Past and Current Findings and Experimental Data}

\subsubsection{DWPF Process History}

The DWPF has been producing HLW glass since 1996. DWPF operations represent a significant source of full-scale radioactive process data with the potential to support the development of the crystal-tolerant approach. Therefore, relevant past and current data from the DWPF and smaller scale melters will be aggregated in a technical report and evaluated. Specifically, any data that describe crystallinity in actual HLW glasses as a function of composition, temperature, temperature distribution in the melter and riser, and possible issues with accumulation of crystals in the melter and riser will be aggregated and reviewed. Furthermore, data will be accumulated regarding the frequency, conditions, and duration of idle periods and other key events for the DWPF melter such as planned outages, scheduled and unscheduled maintenance, and delays in feed preparation. These data will be used to provide insight into the duration and frequency of idle periods that might be expected for actual operation of the WTP HLW melter, since melter idling time will become a key component of a crystal settling model later in this study.

The intent here is to provide an overview of lessons learned, including data that can be used to advance the development and implementation of an empirical model and crystal accumulation limit for WTP. It is acknowledged that these data may be qualitative in nature; however, they may still assist with model validation in later development stages.

\footnotetext{
${ }^{\mathrm{b}}$ It must be recognized that shifting to this approach for DWPF would have to include a critical assessment of any potential riser and pour spout concerns given the current strategy is focused on preventing bulk devitrification in the melt pool.
} 
PNNL-23363

SRNL-STI-2013-00734

Revision 0

\subsubsection{Crystal Settling Studies Literature Review}

A significant amount of crystal settling data has been generated in recent studies. ${ }^{8-14}$ However, there is literature available on the settling behavior of crystals as observed in research-, pilot-, and full-scale melter tests that needs to be reviewed and summarized. A thorough literature review will include descriptions of different methodologies for measuring crystal precipitation, settling, and accumulation in molten glasses. The goal of this review is to identify differences and similarities in the data generated by these tests and to leverage those data to support model development and crystal accumulation studies.

\subsubsection{Assessment of WTP HLW Melter Design}

One of the critical parameters that must be fundamentally understood prior to implementing a crystal-tolerant approach is the location and thickness of a crystal layer that is tolerable (i.e., the areas of the melter where crystals are likely to accumulate and the thickness of layers in those areas that is acceptable before a negative impact on melter operation is expected). Also, previous experiences with pour spout clogging in the SRS test melters and the DWPF melter highlight the need to avoid crystallization in the pour spout. ${ }^{15,16}$ This is of particular importance given the inability to inspect and service the WTP melter discharge riser based on the current design.

The design and dimensions of the WTP HLW melter and melt discharge riser will be evaluated to determine the extent to which the accumulation of crystals could be tolerated without deteriorating melter performance or life expectancy. This assessment will also consider the impact of glass flow currents (glass discharge) on the rate of accumulation and on the possible removal of accumulated crystals from the riser. Variations in temperature profiles in the bulk of the melter and riser, and possible impacts of bubblers on crystal accumulation will be evaluated as well. This information will be needed to support later assessments of crystal accumulation in the actual melter.

The objective is to develop an appropriate set of crystal accumulation related constraints for melter operation. It may be that separate constraints are needed depending on the melter operating scenario. These constraints will be important in determining the impact of later modeling efforts. That is, they will provide part of the basis for determining the benefit (in terms of waste throughput) of shifting from a $T_{1 \%}$ control approach to a crystal-tolerant approach.

\subsection{Develop an Empirical Model of Crystal Accumulation}

The complex nature of crystal nucleation, growth, and accumulation in the HLW melter dictates the development of a model from empirical data. The preliminary empirical model for spinel settling with coefficients $h_{i}$ and $s_{i}$ expressed as a linear function of the mass fractions of seven major components in glass $\left(\mathrm{Al}_{2} \mathrm{O}_{3}, \mathrm{Cr}_{2} \mathrm{O}_{3}, \mathrm{Fe}_{2} \mathrm{O}_{3}, \mathrm{ZnO}, \mathrm{MnO}\right.$, $\mathrm{NiO}$, and others) was developed to calculate crystal accumulation in the glass discharge riser of a HLW melter at $850{ }^{\circ} \mathrm{C} .{ }^{17}$ However, the influence of HLW glass composition on crystal accumulation is hard to deconvolute, especially when combined with the effects of time, temperature, viscosity, and the dynamic flow of glass in a full scale melter. Therefore experimental data gathered from both laboratory and larger scale tests are needed to build a large dataset and validate a model that can be used for process control. The modeling effort will be an iterative process, where model form and parameters are refined and optimized as additional data are gathered. Validation steps in the form of research- and pilot-scale tests will also be included throughout the model development process to guide the modeling work and ensure the value of the effort (i.e., the potential for increased waste loading and waste throughput). 
PNNL-23363

SRNL-STI-2013-00734

Revision 0

\subsubsection{WTP Composition Envelope}

In this task, the most recent available data on projected waste compositions at Hanford will be evaluated to identify a composition envelope for WTP. These data will be combined with the results from the DWPF operating history review report and the WTP melter design and operating strategy to map a time-temperature-composition region of interest for the development of empirical data. Note that practicality will likely dictate that the preliminary model focus on a reduced region in order to demonstrate early progress.

\subsubsection{Glass Selection and Characterization}

A glass test matrix will be designed to systematically cover the composition region of interest based on the range of elemental compositions of HLW at Hanford. Developed glasses will be tested with a double crucible method. ${ }^{8}$ The thickness of an accumulated layer of crystals under static, laboratory conditions will be measured as a function of time and temperature. Glass viscosity as a function of glass composition and temperature will also be measured. Glass viscosity impacts the accumulation rate of crystals, and at the same time may be impacted by the presence of settling crystals. Thus, experimental data will be collected to support development of both the crystal accumulation and viscosity models for WTP.

\subsubsection{Model Fitting and Quantification of Uncertainties}

The experimental data on thickness of accumulated layers and melt viscosity will be fit to numerical models. The preliminary crystal accumulation model will focus on spinel, while an expanded model or additional models (as warranted) will be developed for other crystalline phases that are likely to form when immobilizing Hanford waste, including eskolaite $\left(\mathrm{Cr}_{2} \mathrm{O}_{3}\right)$ and zirconolite $\left(\mathrm{CaZrTi}_{2} \mathrm{O}_{7}\right)$. These models will be related to the melter constraints identified earlier, and validated through melter testing.

Uncertainties associated with the model will be incorporated such that the model is of a form that can be used for process control of an operating facility. The inclusion of uncertainties will ensure that predictions of accumulation rates are maintained below some critical threshold value for targeted WTP melter feeds. The inclusion of uncertainties will also allow for evaluations of the benefits of incorporating the new model (in terms of achievable waste loadings, canister count, and glass volume) as compared to the existing WTP $T_{1 \%}$ model and the DWPF $T_{L}$ model.

An evaluation such as this would be crucial to demonstrate the potential gains if such an approach were to be pursued at DWPF before being implemented at WTP. The first step toward employing a crystal accumulation approach in DWPF would be based on a paper study assessment to demonstrate the improvements in waste loading that could be achieved if the operational strategy shifted from the current $T_{L}$ approach to a crystal accumulation approach. The paper study would use projected sludge batch information from the latest version of the Savannah River Remediation (SRR) HLW Systems Plan. Comparisons could be made of maximum achievable waste loadings through the use of the current process control algorithms to an alternative process control system where the current $T_{L}$ model would be substituted by the proposed accumulation model. If significant increases in waste loading could be demonstrated through the paper study, validation of the approach through experimental studies would be required to reduce the risk of higher waste loadings to manageable levels.

\subsubsection{Model Validation}

Selected WTP glass compositions will be tested with larger scale melter platforms to validate the accumulation rate of crystals from laboratory scale tests. The impact of transitioning from static 
PNNL-23363

SRNL-STI-2013-00734

Revision 0

conditions in crucible scale melts to the dynamic melt pool of a scaled melter will be evaluated, including agitation of the melt pool via bubbling.

Agitation of the melt pool, thermal currents within the glass, and flow during pouring have the potential to sweep crystals from the melter and riser as canisters are poured. Scale melters will be used to quantify the accumulated crystal layer during idling and the fraction of the spinel discharged in the melt pours. The resulting data will be used to validate the predictive models and identify need for model improvements.

\subsubsection{Model Refinement}

As the laboratory and scale-up tests described above are completed and experimental data are available, the form of the crystal accumulation model and its parameters will be refined and optimized through an iterative process.

\subsection{Identify Engineering Methods for Monitoring and Mitigating Crystal Accumulation}

It is recognized that operating a HLW melter with some accepted amount of crystallization increases the risk of reduced melter performance or life expectancy. For example, crystals may accumulate in the riser of the melter, restricting or even blocking the discharge of the molten glass into canisters. The modeling and constraint approach described in this road map will be developed to avoid adverse impacts of crystal accumulation in the melter. However, to provide additional confidence in this approach (i.e., to account for the potential occurrence of off-normal events), engineering methods for monitoring and mitigating crystal accumulation in the melter will be developed in parallel.

\subsubsection{Develop Online Monitoring of Crystal Accumulation in the Riser}

Technologies such as ultrasonic measurement and an electrical conductivity probe method will be developed and demonstrated to monitor in real time accumulation of crystals in the riser. Testing will include accumulation of spinel crystals in standard conductivity solutions and actual glass melts. Developed methods will supplement the crystal accumulation model and provide an additional confidence for melter operation.

\subsubsection{Develop and demonstrate engineering solutions to mitigate accumulation of crystals}

It is possible that a relatively simple design change to the WTP HLW melter, such as changing the bottom of the riser from a horizontal surface to a sloped surface, may reduce the risk of crystal accumulation. In addition, a specialized tool may be developed to sweep or extract crystals from the riser during idle periods. An alternative draining method may also be practical. This task will evaluate the practicality of such solutions.

\subsubsection{Fluid Dynamic Modeling of Riser Accumulation and Clearing}

Scaled melter operation will require a significant investment of time and resources. A simple column test and scaled version of the riser made from Plexiglas using silicone oils with viscosities similar to those of glass with the addition of spinel crystals may be used to provide data on the relative packing density, shear-strength, and rheology of the accumulated layer, and crystal accumulation and clearing of the riser. The combination of transparency and room temperature operation will make this system far easier to use for multiple test conditions than a scaled melter. The data generated will support fluid dynamic modeling to evaluate the impact of various parameters (e.g., thickness of the accumulated layer, packing density, crystal size, and crystal agglomeration) on removal of crystals from the riser. It is expected that this model will be incorporated as an integral component of the crystal-tolerant strategy. It is recognized that 
PNNL-23363

SRNL-STI-2013-00734

Revision 0

precipitation of spinel crystals, their mutual interaction including agglomeration, and their reaction or bonding with refractory or other crystals need to be considered when designing experiments to support this effort.

\subsection{Stages, Durations, and Deliverables}

A summary of the stages of the road map described above, their estimated durations, and deliverables is provided in Table 3-1. 
Table 3-1. Road Map Stages, Durations, and Deliverables.

\begin{tabular}{|c|c|c|}
\hline Stage & $\begin{array}{l}\text { Estimated } \\
\text { Duration }\end{array}$ & Deliverables \\
\hline - Review DWPF process history & FY14 & $\begin{array}{l}\text { - Technical report or publication } \\
\text { - Determination of duration and temperatures of idling } \\
\text { periods appropriate for crystal accumulation experiments }\end{array}$ \\
\hline - Review crystal settling studies & FY14 & $\begin{array}{l}\text { - Technical report or publication } \\
\text { - Leverage past and current data from laboratory-, research-, } \\
\text { pilot-, and full-scale melter tests to support model } \\
\text { development and crystal accumulation studies }\end{array}$ \\
\hline - WTP HLW design review & FY14-FY15 & $\begin{array}{l}\text { - Technical report or publication } \\
\text { - Identify tolerable thickness of accumulated crystal layer in } \\
\text { the melter and the riser } \\
\text { - Consensus on crystal accumulation constraints for melter } \\
\text { operation }\end{array}$ \\
\hline - Crystal accumulation studies & FY14-FY18 & - Document results in publications \\
\hline - Develop preliminary spinel accumulation model & FY15 & - Document results in publication \\
\hline $\begin{array}{l}\text { - Demonstrate utility of crystal accumulation } \\
\text { approach for DWPF. }\end{array}$ & FY15 & $\begin{array}{l}\text { - Document findings in paper study } \\
\text { - Uncertainties quantified } \\
\text { - Verification the model implementation shows value in } \\
\text { increasing waste throughput }\end{array}$ \\
\hline - Refine spinel accumulation model & FY16 & - Document results in publication \\
\hline - Test utility of refined model & FY16 & $\begin{array}{l}\text { - Uncertainties quantified } \\
\text { - Verification the model implementation shows value in } \\
\text { increasing waste throughput }\end{array}$ \\
\hline $\begin{array}{l}\text { - Develop online monitoring of crystal } \\
\text { accumulation in the pour riser }\end{array}$ & FY14-FY15 & $\begin{array}{l}\text { - Demonstration of crystal accumulation monitoring in the } \\
\text { research-scale melter } \\
\text { - Document results in publication }\end{array}$ \\
\hline $\begin{array}{l}\text { - Develop and demonstrate engineering solutions } \\
\text { to mitigate accumulation of crystals }\end{array}$ & FY16-FY18 & $\begin{array}{l}\text { - Document results in technical report } \\
\text { - Demonstrate tool for removing crystals from the riser in the } \\
\text { research-scale melter }\end{array}$ \\
\hline
\end{tabular}


Table 3-1. Road Map Stages, Durations, and Deliverables. (continued)

\begin{tabular}{|c|c|c|}
\hline Stage & $\begin{array}{l}\text { Estimated } \\
\text { Duration }\end{array}$ & Deliverables \\
\hline $\begin{array}{l}\text { - Develop and perform scaled melter tests to } \\
\text { validate laboratory-scale data }\end{array}$ & FY16-FY17 & - Document results in publication \\
\hline $\begin{array}{l}\text { - Fluid Dynamic Modeling of Riser Accumulation } \\
\text { and Clearing }\end{array}$ & FY16-FY18 & $\begin{array}{l}\text { - Demonstrate room temperature test bed for crystal settling } \\
\text { and clearing } \\
\text { - Develop fluid dynamic model of spinel accumulation and } \\
\text { clearing in melt discharge riser } \\
\text { - Document results in publication }\end{array}$ \\
\hline $\begin{array}{l}\text { - Incorporate scale melter data and fluid dynamic } \\
\text { data into spinel accumulation model }\end{array}$ & FY17 & - Technical report or publication \\
\hline - Test utility of refined model & FY17 & $\begin{array}{l}\text { - Uncertainties quantified } \\
\text { - Verification the model implementation shows value in } \\
\text { increasing waste throughput }\end{array}$ \\
\hline $\begin{array}{l}\text { - Select and perform Stage } 3 \text { crystal accumulation } \\
\text { studies } \\
\text { - Determine whether spinel model is sufficient or } \\
\text { other crystalline phases must be incorporated } \\
\end{array}$ & FY17-FY18 & - Document results in publication \\
\hline $\begin{array}{l}\text { - Refine and finalize crystal accumulation } \\
\text { model(s) }\end{array}$ & FY18-FY19 & - Document results in publication \\
\hline $\begin{array}{l}\text { Demonstrate utility of model(s) using current } \\
\text { SRS systems plan and WTP projected waste } \\
\text { compositions }\end{array}$ & FY19 & - Technical report \\
\hline $\begin{array}{l}\text { - Develop strategy for demonstrating } \\
\text { implementation of crystal accumulation model(s) } \\
\text { at DWPF }\end{array}$ & FY19 & - Technical report \\
\hline
\end{tabular}


PNNL-23363

SRNL-STI-2013-00734

Revision 0

\subsection{References}

1. Certa, P. J., R. D. Adams, G. K. Allen, J. D. Belsher, P. A. Empey, J. H. Foster, T. M. Hohl, R. T. Jasper, R. A. Kirkbride, R. L. Lytle, F. L. Meinert, J. S. Ritari, R. M. Russell, K. R. Seniow, E. B. West, M. N. Wells, and L. M. Bergmann, "River Protection Project System Plan," U.S. Department of Energy Report ORP-11242, Revision 6, U.S. Department of Energy - Office of River Protection, Richland, WA (2011).

2. Vienna, J. D., D. C. Skorski, D. S. Kim, and J. Matyáš, "Glass Property Models and Constraints for Estimating the Glass to be Produced at Hanford by Implementing Current Advanced Glass Formulation Efforts," U.S. Department of Energy Report EWG-RPT-003, Revision 0, Pacific Northwest National Laboratory, Richland, WA (2013).

3. Belsher, J. D. and F. L. Meinert, "High-Level Waste Glass Formulation Model Sensitivity Study 2009 Glass Formulation Model Versus 1996 Glass Formulation Model," U.S. Department of Energy Report RPP-RPT-42649, Revision 0, Washington River Protection Solutions, Richland, Washington (2009).

4. Vienna, J. D. and D. S. Kim, "High-Level Waste Vitrification and Glass Formulation," U.S. Department of Energy Report PNNL-SA-99036, Pacific Northwest National Laboratory, Richland, WA (2013).

5. Iverson, D. C., K. J. Imrich, D. F. Bickford, J. T. Gee, C. F. Jenkins, and F. M. Heckendorn, "Examination of DWPF Melter Materials After 8 Years of Service," U.S. Department of Energy Report WSRC-MS-2003-00318, Washington Savannah River Company, Aiken, SC (2003).

6. Vienna, J. D., D. S. Kim, M. J. Schweiger, J. S. McCloy, J. Matyáš, G. F. Piepel, and S. K. Cooley, “Test Plan: Enhanced Hanford Waste Glass Models," U.S. Department of Energy Report TP-EWG-00001, Revision 0, Pacific Northwest National Laboratory, Richland, WA (2013).

7. Matlack, K. S., W. K. Kot, W. Gong, W. Lutze, I. L. Pegg, and I. Joseph, "Effects of High Spinel and Chromium Oxide Crystal Contents on Simulated HLW Vitrification in DM100 Melter Tests," U.S. Department of Energy Report VSL-09R1520-1, Vitreous State Laboratory, The Catholic University of America, Washington, DC (2009).

8. Matyáš, J., J. D. Vienna, A. Kimura, M. Schaible, and R. M. Tate, "Development of CrystalTolerant Waste Glasses"; pp. 41-51 in Ceramic Transactions, Vol. 222, Advances in Materials Science for Environmental and Nuclear Technology. Edited by K. M. Fox, E. N. Hoffman, N. Manjooran and G. Pickrell. John Wiley \& Sons, Inc., Hoboken, NJ, 2010.

9. Matyáš, J., J. D. Vienna, and M. Schaible, "Determination of Stokes Shape Factor for Single Particles and Agglomerates”; pp. 195-203 in Ceramic Transactions, Vol. 227, Advances in Materials Science for Environmental and Nuclear Technology II. Edited by S. K. Sundaram, T. Ohji, K. M. Fox and E. N. Hoffman. John Wiley \& Sons, Inc., Hoboken, NJ, 2011.

10. Matlack, K. S., H. Gan, M. Chaudhri, W. K. Kot, and I. L. Pegg, "Melter Throughput Enhancements for High-Iron HLW," U.S. Department of Energy Report VSL-12R2490-1, Revision 0, Vitreous State Laboratory, The Catholic University of America, Washington, DC (2012). 
PNNL-23363

SRNL-STI-2013-00734

Revision 0

11. Matyáš, J., A. R. Huckleberry, C. P. Rodriguez, J. B. Lang, A. T. Owen, and A. A. Kruger, "Empirical Model for Formulation of Crystal-Tolerant HLW Glasses"; pp. 121-128 in Ceramic Transactions, Vol. 236, Advances in Materials Science for Environmental and Energy Technologies. Edited by T. Ohji, M. Singh, E. Hoffman, M. Seabaugh and G. Yang. John Wiley \& Sons, Inc., Hoboken, NJ, 2012.

12. Matyáš, J., D. P. Jansik, A. T. Owen, C. A. Rodriguez, J. B. Lang, and A. A. Kruger, "Impact of Particle Agglomeration on Accumulation Rates in the Glass Discharge Riser of HLW Melter"; pp. 59-68 in Ceramic Transactions, Vol. 241, Advances in Materials Science for Environmental and Energy Technologies II. Edited by J. Matyáš, T. Ohji, X. Liu, M. P. Paranthaman, R. Devanathan, K. M. Fox, M. Singh and W. Wong-Ng. John Wiley \& Sons, Inc., Hoboken, NJ, 2013.

13. LaMont, J. and P. Hrma, “A Crucible Study of Spinel Settling in a High-Level Waste Glass”; pp. 343-348 in Ceramic Transactions, Vol. 87, Environmental Issues and Waste Management Technologies in the Ceramic and Nuclear Industries III. Edited by D. K. Peeler and J. C. Marra. The American Ceramic Society, Westerville, OH, 1998.

14. Kloužek, J., J. Alton, T. J. Plaisted, and P. Hrma, "Crucible Study of Spinel Settling in HighLevel Waste Glass”; pp. 301-308 in Ceramic Transactions, Vol. 119, Environmental Issues and Waste Management Technologies in the Ceramic and Nuclear Industries VI. Edited by D. R. Spearing, G. L. Smith and R. L. Putman. The American Ceramic Society, Westerville, OH, 2001.

15. Jantzen, C. M., A. D. Cozzi, and N. E. Bibler, "High Level Waste Processing Experience with Increased Waste Loadings”; pp. 31-49 in Ceramic Transactions, Vol. 168, Environmental Issues and Waste Management Technologies in the Ceramic and Nuclear Industries X. Edited by J. D. Vienna, C. C. Herman and S. L. Marra. The American Ceramic Society, Westerville, OH, 2005.

16. Fox, K. M., "Crystallization in High Level Waste (HLW) Glass Melters: Operational Experience from the Savannah River Site,” U.S. Department of Energy Report SRNL-STI-201300724, Revision 0, Savannah River National Laboratory, Aiken, SC (2014).

17. Matyáš, J., A. R. Huckleberry, C. P. Rodriguez, J. B. Lang, A. T. Owen, and A. A. Kruger, "Empirical Platform for Mitigation of Crystal Accumulation in Continuous Melters Processing Radioactive Waste,” International Journal of Applied Glass Science, (2013, submitted). 
PNNL-23363

SRNL-STI-2013-00734

Revision 0

Distribution:

$\begin{array}{llll}\text { J. Matyáš } & \text { PNNL } & \text { J. W. Amoroso } & \text { SRNL, 999-W } \\ \text { J. D. Vienna } & \text { PNNL } & \text { T. B. Brown } & \text { SRNL, 773-A } \\ \text { M. J. Schweiger } & \text { PNNL } & \text { S. D. Fink } & \text { SRNL, 773-A } \\ & & \text { K. M. Fox } & \text { SRNL, 999-W } \\ \text { A. A. Kruger } & \text { DOE-ORP } & \text { C. C. Herman } & \text { SRNL, 773-A } \\ \text { P. Hrma } & \text { DOE-ORP } & \text { E. N. Hoffman } & \text { SRNL, 999-W } \\ \text { W. F. Hamel, Jr. } & \text { DOE-ORP } & \text { F. C. Johnson } & \text { SRNL, 999-W } \\ & & \text { S. L. Marra } & \text { SRNL, 773-A } \\ & & \text { D. H. McGuire } & \text { SRNL, 999-W } \\ & & \text { D. K. Peeler } & \text { SRNL, 999-W } \\ & & \text { F. M. Pennebaker } & \text { SRNL, 773-42A } \\ & & \text { W. R. Wilmarth } & \text { SRNL, 773-A }\end{array}$

